\title{
AL-AZHAR
}

The Official Publication of The

Assiut Dental Journal

Faculty of Dental medicine,

Al-Azhar Assiut Uniuersity.

Equpt

AADJ, Vol. 3, No. 2, October (2020) - PP. 113:120

ISSn 2682-2822

\section{Tri-Calcium Phosphate Combined With Collagen Membrane in Treatment of Intraosseous Defects in Chronic Periodontitis Patients (Clinical and Radiographic Study)}

\author{
Hany Kamal Mohamed ${ }^{* 1}$, Ebrahim Mowafy ${ }^{1}$, Khalid S Hassan ${ }^{1}$
}

Codex : 14/2020/10

Aadj@azhar.edu.eg

\section{KEYWORDS}

$\beta$-TCP, Collagen membrane,

Intraosseous defects, Periodontitis, Probing pocket depth

1. Department of Oral Medicine, Periodontology, Oral Diagnosis and Dental Radiology, Faculty of Dental medicine, (Assiut, Boys), Al-Azhar University, Egypt.

* Corresponding Author e-mail: hanykama197@ azhar.edu.eg

\begin{abstract}
Aim: This study aims to evaluate clinically and radiographically the effect of tricalcium phosphate combined with collagen membrane in treatment of intraosseous defects in chronic periodontitis patients. Subjects and methods: Fifteen patients with chronic periodontitis with intraosseous defects has pocket depth $>6 \mathrm{~mm}$ and $\mathrm{CAL} \geq$ $5 \mathrm{~mm}$ after cause related therapy on both sides, with radiographic evidence of vertical bone loss. Following phase I therapy were classified into two groups, group A received defects received open flap debridement alone and group B received open flap surgery augmented with tricalcium phosphate bone graft covered with collagen membrane . Clinical and radiographic parameters were recorded at baseline,3, 6,9 and 12 months postoperatively. Results: Both treatment groups showed a significant probing pocket depth (PPD) reduction, clinical attachment gain, increase bone density 12 months after surgery compared with baseline. However, there was a highly significant PPD reduction and clinical attachment gain when collagen membrane was added to $\beta$-TCP. Conclusion: $\beta$-TCP plus collagen membrane may lead to improved clinical outcomes compared to open flap debridement alone.
\end{abstract}

\section{INTRODUCTION}

Periodontal therapy is performed with the primary objectives of gaining access to the diseased sites, achieving reduction in pocket depth, arresting further disease progression and finally restoring the periodontal tissues lost due to disease process. The ultimate aim is to achieve periodontal regeneration via new attachment formation. Regeneration has been defined as the reproduction or reconstitution of a lost or injured part to restore the architecture and function of the periodontium ${ }^{1}$.

Open flap debridement offers only limited potential towards recovering the lost periodontal structures ${ }^{2}$. Various grafting modalities have been used for periodontal tissue regeneration such as autogenous $\mathrm{s}^{3,4}$ and allogenic bone grafts ${ }^{5}$ but none has been established as a gold 
standard in the treatment of intrabony defects, given their own associated limitations ${ }^{6}$.

Guided tissue regeneration (GTR), the procedure in which a barrier is utilized to exclude epithelium from the root surfaces ${ }^{7}$, has been shown to partially regenerate lost periodontal tissue with new bone, periodontal ligament, and cementum. Several materials, both non-absorbable and bioabsorbable barriers have been developed and modified in an attempt to achieve complete periodontal regeneration ${ }^{8}$. More recently, the membrane barriers have also been applied for regenerating bone surrounding peri-implant defects, in the so-called guided bone regeneration (GBR) procedure?

The GTR with both nonbioabsorbable and bioabsorbable membranes showed that GTR improved attachment gain, reduced pocket depth, and resulted in less gingival recession and more hard-tissue fill than did open flap debridement (OFD) alone. The use of non-bioabsorbable membranes increases risk of membrane exposure and bacterial colonization and thus may inhibit healing. Bioabsorbable membranes, including collagen membranes (CM), have been developed for prevent these problems ${ }^{10}$.

Collagen membrane appears to be an ideal choice for an absorbable GTR barrier due to collagen material possess many advantages including hemostasis, chemotaxis for periodontal ligament (PDL) fibroblasts and gingival fibroblasts ${ }^{11,12}$ and gingival fibroblasts ${ }^{13}$, weak immunogenicity ${ }^{14-16}$, easy manipulation, and ability to augment tissue thickness ${ }^{17}$.

The application of bone substitutes is based on the assumption that these materials facilitate the regeneration of alveolar bone and root cementum, and create the space needed for the regeneration process. Some have been attempted with varying degrees of success. Among them, synthetic grafts or alloplastic materials have been at great interest in periodontal regeneration. The osteoconductive action of beta-Tricalcium phosphate ( $\beta$-TCP) has been subjected to increased attention due to various factors, including its porous micromorphology, interconnecting bone structure and full resorbability, which is synchronous with bone remodeling ${ }^{18}$.

For the purpose of the present study, the primary research question was as follows: does grafting using tricalcium phosphate combined with collagen membrane, enhance the outcomes of intraossous defects in chronic periodontitis patients.

\section{PATIENTS AND METHODS}

This study was designed as a randomized controlled clinical trial carried out on 15 patients of both sexes ( 5 females and 10 males) ranged in age from 30-45 years old, with mean age of $41.5 \pm 3.4$ years. All Patients submitted to this study were from those attending at the outpatient dental clinic, Department of Oral Medicine, Periodontology, Oral Diagnosis and Dental Radiology, Faculty of Dental Medicine Al -Azhar University (Assiut branch). All patients were diagnosed as having chronic periodontitis with intrabony defects by clinical and radiographic examination. All patients received a description of the nature, potential risks and benefits of their participation in the study and signed a written informed consent form. The study protocol was approved by the ethical committee, Faculties of Dental Medicine, Al-Azhar University. All eligible patients were thoroughly informed of the nature, potential risks and benefits of their participation in the study and signed their informed consent documents.

\section{Inclusion criteria:}

All patients were free from any systemic disease according to the history and clinical examination.To be included in the study, all patients presenting with chronic periodontitis with intraosseous defects has pocket depth $>6 \mathrm{~mm}$ and $\mathrm{CAL} \geq 5 \mathrm{~mm}$ after cause related therapy on both sides, with radiographic evidence of vertical bone loss. 


\section{Periodontal and radiographic evaluation:}

1. Periodontal evaluation and clinical parameter were recorded before surgical procedures included vertical probing depth (VPD) ${ }^{19}$, Clinical Attachment Level (CAL) ${ }^{20}$, plaque $^{21}$ and gingival indices ${ }^{22}$.

2. Radiographic evaluation was done at; baseline, 3, 6, 9 and 12 months post surgically. A standardized periapical radiographs were taken using long cone parallel technique, customized bite, metal rod and parallel dental film positioning system.

\section{Surgical procedures:}

A full thickness open flap surgery was performed. The incision was extended to interproximal line angles of teeth to provide adequate flap reflection, complete debridement of exposed root surfaces was performed by a combination of ultrasonic and hand instrumentation. Group A patients received open flap debridement alone, Group B patients received open flap surgery plus Tricalcium phosohate bone graft plus collagen membrane (Fig.1, 2), the flaps were sutured coronally with $4 / 0$ absorbable polyglycopeptide surgical suture with sling or horizontally interrupted sutures.

\section{Post-surgical instructions and medications:}

Patients were placed on systemic antibiotic, analgesic for one week and mouth wash for 4 weeks, Patients were advised with repeated application of an ice pack over the area of the face related to the surgery for one day to avoid post-surgical edema. In the 1 st week post surgically patients were asked to avoid sticky, spicy, hard and crispy food. The patients were instructed to discontinue tooth brushing around the surgical sites during the initial 10 days after surgery.

\section{Post-surgical Evaluations:}

1. All patients were evaluated clinically by following measurement plaque index (PI), gingival index(GI), vertical probing depth (VPD), Clinical Attachment Level (CAL) were recorded at $3,6,9$ and 12 months post surgically.

2. Standardized periapical radiographs were repeated at3, 6, 9 and 12 months postsurgical (Fig. 2).

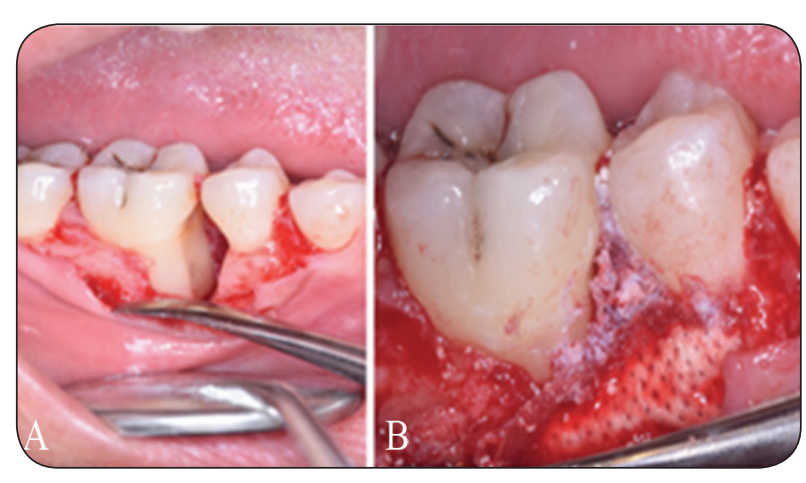

Fig. (1) A. intrabony pocket, B. $\beta$-TCP plus Collagen membrane placement in the defect.

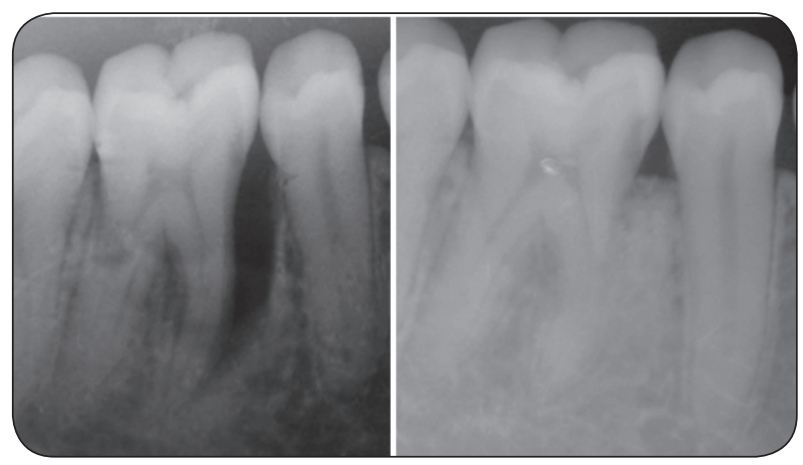

Fig. (2) Show intrabony defect at base line and 12 months postsurgically after treatment with $\beta$-TCP plus collagen membrane.

\section{Statistical analysis:}

The data were collected, tabulated and statistically analyzed by IBM ${ }^{\circledR}$ SPSS ${ }^{\circledR}$ Statistics Version 20 for Windows using ANOVA test. 1-Data were explored for normality using KolmogorovSmirnov and Shapiro-Wilk tests, Plaque index and Gingival index data showed non-parametric (not-normal) distribution, while Pocket depth, CAL and Bone density data showed parametric (normal) distribution. 2-Pearson test was used to test the correlation between different variables. The significance level was set at $\mathrm{P} \leq 0.05$. 


\section{RESULTS}

Table (1) Demonstrate the statistical comparisons of clinical parameters at time intervals; baseline, 6 month and 12 month in group A and group B:

\begin{tabular}{|c|c|c|c|c|}
\hline Parameters & Intervals & Group A & Group B & p-value \\
\hline \multirow{4}{*}{ PI } & Baseline & $0.39 \pm 0.19$ & $0.43 \pm 0.15$ & $0.591 \mathrm{~ns}$ \\
\hline & $6 \mathrm{~m}$ & $0.45 \pm 0.11$ & $\begin{array}{c}0.46 \pm 0.13 \\
0.13\end{array}$ & $0.938 \mathrm{~ns}$ \\
\hline & $12 \mathrm{~m}$ & $0.62 \pm 0.09$ & $0.63 \pm 0.12$ & $0.905 \mathrm{~ns}$ \\
\hline & p-value & $<0.001 *$ & $<0.001 *$ & \\
\hline \multirow{4}{*}{ GI } & Baseline & $0.26 \pm 0.13$ & $0.27 \pm 0.12$ & $0.488 \mathrm{~ns}$ \\
\hline & $6 \mathrm{~m}$ & $0.37 \pm 0.07$ & $0.43 \pm 0.13$ & $0.261 \mathrm{~ns}$ \\
\hline & $12 \mathrm{~m}$ & $0.63 \pm 0.09$ & $0.59 \pm 0.12$ & $0.410 \mathrm{~ns}$ \\
\hline & $\mathrm{p}$-value & $<0.001 *$ & $<0.001 *$ & \\
\hline \multirow{4}{*}{ PD } & Baseline & $7.08 \pm 0.65$ & $6.94 \pm 0.82$ & $0.677 \mathrm{~ns}$ \\
\hline & $6 \mathrm{~m}$ & $6.32 \pm 0.61$ & $4.22 \pm 0.72$ & $<0.001 *$ \\
\hline & $12 \mathrm{~m}$ & $5.70 \pm 0.72$ & $3.61 \pm 0.66$ & $<0.001^{*}$ \\
\hline & p-value & $<0.001 *$ & $<0.001 *$ & \\
\hline \multirow{4}{*}{ CAL } & Baseline & $5.38 \pm 0.46$ & $5.56 \pm 0.77$ & $0.534 \mathrm{~ns}$ \\
\hline & $6 \mathrm{~m}$ & $4.79 \pm 0.48$ & $3.03 \pm 0.57$ & $<0.001 *$ \\
\hline & $12 \mathrm{~m}$ & $4.19 \pm 0.51$ & $2.41 \pm 0.52$ & $<0.001 *$ \\
\hline & p-value & $<0.001^{*}$ & $<0.001^{*}$ & \\
\hline \multirow{4}{*}{$\begin{array}{l}\text { Bone } \\
\text { density }\end{array}$} & Baseline & $88.07 \pm 5.75$ & $86.35 \pm 3.57$ & $0.431 \mathrm{~ns}$ \\
\hline & $6 \mathrm{~m}$ & $96.15 \pm 5.09$ & $116.95 \pm 4.04$ & $<0.001^{*}$ \\
\hline & $12 \mathrm{~m}$ & $103.60 \pm 6.26$ & $123.43 \pm 4.35$ & $<0.001 *$ \\
\hline & P-value & $<0.001 *$ & $<0.001 *$ & \\
\hline
\end{tabular}

Group $a=$ open flap debridement alone Group $b=$ $\beta-T C P+$ collagen membrane PI=plaque Index $G I=$ Gingival Index $P D=$ pocket depth $C A L=$ Clinical Attachment Level $B D=B o n e$ Density significant*; $(p<0.05)$ ns; non-significant $(p>0.05)$.

\section{DISCUSSION}

The primary goal of periodontal therapy is the maintenance of the natural dentition health and comfortable function. When periodontal disease has caused a loss of the attachment apparatus, optimal care seeks to regenerate the periodontal tissues to its pre-disease state. Different modalities such as bone grafts and their synthetic substitutes have been used in an attempt to gain this therapeutic end point ${ }^{23}$.

$\beta$-Tricalcium phosphate ( $\beta$-TCP) has been selected in the present study as bone replacement graft to treat intraosseous defects, which is a porous form of calcium phosphate, with similar proportions of calcium and phosphate to cancellous bone $^{24}$. It's a biocompatible and can use succefully as osteoconductive material. In most cases, is fully resorbed $^{25}$.The material is well tolerated, and until now, no adverse effects such as allergic reactions or rejection of the particles have been reported .Moreover, there is also evidence that it possesses the potential to inhibit osseous resorption ${ }^{26}$.

Collagen membrane is bioabsorbable so we used it to avoid a second surgical procedure which is necessary to remove non-bioabsorbable membranes, which put the newly formed tissues in compromised situation. Moreover, flap elevation for membrane removal may result in crestal bone resorption ${ }^{27}$, decrease coverage of the newly formed tissue, thus interrupting the healing process ${ }^{28}$, and increases risk of membrane exposure and bacterial colonization which lead to inhibit healing ${ }^{29}$.

The plaque and gingival indices showed nonsignificant difference between the test and control groups. Within the test and control groups the differences between the values at various time intervals were significant. The results could be due to the lack of improvement in homecare.

The probing pocket depth in the present study indicated that the mean value of probing pocket depth in group (A) was $7.08 \pm 0.65 \mathrm{~mm}$ at baseline that reduced to $5.7 \pm 0.72 \mathrm{~mm}$ following 12 months 
post-surgery. On the other hand, group (B) patients recorded a mean value of probing pocket depth 6.94 $\pm 0.82 \mathrm{~mm}$ at baseline compared to $3.61 \pm 0.66$ $\mathrm{mm}$ after 12 months post-surgery.These findings indicated that $\beta$-TCP bone graft in combination with collagen membrane appeared to be potential modality in periodontal regeneration.

A similar finding was reported by D Trinath Kishore et al $\mathbf{2 0 1 3}^{30}$ as they had result of pocket depth improvement from $6.8 \pm 1.3 \mathrm{~mm}$ to $2.5 \pm 0.7$ mm after 9 months post-surgery. The reduction in probing pocket depth after treatment with $\beta-\mathrm{TCP}+\mathrm{CM}$ can be attributed to the reduction in inflammation and shrinkage of the pocket wall due to the placement graft material into which modify the gingival tissue consistency and thereby impede penetration of periodontal probe.

The clinical attachment level in the present study indicated that the mean value of clinical attachment level in group (A) was $5.38 \pm 0.46 \mathrm{~mm}$ at baseline that reduced to $4.19 \pm 0.51 \mathrm{~mm}$ following 12 months post-surgery. On the other hand, group (B) patients recorded a mean value of clinical attachment level $5.56 \pm 0.77 \mathrm{~mm}$ at baseline compared to $2.41 \pm 0.52$ $\mathrm{mm}$ after 12 months post-surgery. These findings indicated that $\beta$-TCP bone graft in combination with collagen membrane may lead to favorable clinical result .A similar findings was reported by $\mathbf{D}$ Trinath Kishore et al $\mathbf{2 0 1 3}^{30}$ as they had result of clinical attachment level improvement from $4.9 \pm 2.7$ to $1.8 \pm$ $2.4 \mathrm{~mm}$ after 9 months post-surgery. These findings were in accordance with other studies ${ }^{31-33}$. The gain in the clinical attachment level was attributed to resolution of tissue inflammation, reformation of collagen fibers and new attachment to the root surface and bone fill.

The bone density in the present study indicated that the mean value of bone density in group A was $88.07 \pm 5.75 \mathrm{~mm}$ at baseline that elevated to $103.60 \pm$ $6.26 \mathrm{~mm}$ following 12 months post-surgery. On the other hand, group B patients recorded a mean value of bone density $86.35 \pm 3.57 \mathrm{~mm}$ at baseline compared to $123.43 \pm 4.35 \mathrm{~mm}$ after 12 months post-surgery. $\beta$-TCP bone graft in combination with collagen membrane gives good results in periodontal regeneration. A similar findings was reported by D Trinath Kishore et al $\mathbf{2 0 1 3}^{30}$ but he made radiographic evaluation for the changes in alveolar bone was done as the methodology explained by Charlene BK et al $1987^{34}$ who measure the defect fill . D Trinath Kishore et al $\mathbf{2 0 1 3}^{30}$ found the mean defect fill was (97.4\%) after 9 months post-surgery.

The results of the present study are consistent with Garrett's assessment that in controlled clinical trials treating furcation defects and intraosseous defects with non-absorbable and absorbable synthetic graft materials have consistently demonstrated clinical advantages beyond that achieved by debridement alone ${ }^{35}$.

\section{CONCLUSION}

The combination of beta tricalcium phosphate and collagen membrane exhibit an enhanced synergetic effect in filling of the intrabony defect, suggesting that $\beta$-TCP plus collagen membrane may lead to improved clinical outcomes compared to open flap debridement alone.

\section{REFERENCES}

1. American Academy of Periodontology. Glossary of periodontal terms, 3rd edn. Chicago: Am Acad Periodontol 1992.42

2. Sander L, Karring T. Healing of periodontal lesions in monkeys following the guided tissue regeneration procedure. A histological study. J Clin Periodontol.1995; 22:332-7.

3. Orsini M, Orsini G, Benlloch D, Aranda J, Sanz M. Long-term clinical results on the use of bone replacement grafts in the treatment of intrabony periodontal defects. Comparison of the use of autogenous bone graft plus calcium sulfate to autogenous bone graft covered with a bioabsorbable membrane. J Periodontol. 2008; 79:1630-37.

4. Cochran D, Jones A, Heijl L, Mellonig J, Schoolfield J, King G. Periodontal regeneration with a combination of enamel matrix proteins and autogenous bone grafting. J Periodontol. 2003; 74:1269-78. 
5. Hoidal M, Grimard B, Mills M, Schoolfield J, Mellonig J, Mealey B. Clinical evaluation of demineralized freezedried bone allograft with and without enamel matrix derivative for the treatment of periodontal osseous defects in humans. J Periodontol. 2008; 79:2273-80.

6. Petite $\mathrm{H}$ et al. Tissue engineered bone regeneration. Nat Biotechnol.2000; 18:959-63.

7. David G ,Braden C,James T ,Marlin E ,Jonathan L. Gray Clinical Evaluation of Guided Tissue Regeneration in the Treatment of Maxillary Class II Molar Furcation Invasions. J Periodontol 1991;62:353-60

8. Bunyaratavej P and Wan H. Collagen membranes: a review. J periodontal 2001; 72: 215-29.

9. Fritz ME. Implant therapy. II. Ann Periodontol 1996;1: 796-815.

10. Tonetti MS, Prato GP, Cortellini P. Factors affecting the healing response of intrabony defects following guided tissue regeneration and access flap surgery. J Clin Periodontol 1996 23:548-56.

11. Postlethwaite AE, Seyer JM, Kang AH. Chemotactic attraction of human fibroblasts to type I, II, and III col- lagens and collagen derived peptides. Proc Natl Acad Sci (USA) 1978;75:871-75.

12. Yaffe A, Ehrlich J, Shoshan S. Restoration of periodontal attachment employing enriched collagen solution in the dog. J Periodontol 1984;55:623-28.

13. Locci P, Calvitti M, Belcastro S, et al. Phenotype expression of gingival fibroblasts cultured on membranes used in guided tissue regeneration. J Periodontol 1997;68:857863.

14. Cooperman L \& Michaeli D. The immunogenicity of injectable collagen I. A 1-year prospective study. J Am Acad Dermatol 1984;10:638-46.

15. Sableman E. Biology, Biotechnology and Biocompati- bility of Collagen. Biocompatibility of Tissue Analogs, 1st ed. Boca Raton, FL: CRC Press, Inc; 1985:27.

16. Schlegel AK, Möhler H, Busch F , Mehl A. Preclinical and clinical studies of a collagen membrane (Bio-Gide). Biomaterials 1997;18:535-38.

17. Pitaru S, Tal H, Soldinger M, Noff M. Collagen membranes prevent apical migration of epithelium and support new connective tissue attachment during periodontal wound healing in dogs. J Periodont Res 1989;24:247- 53.

18. Knowles J. A review article: Phosphate glasses for biomedical applications. J Mater Chem.2003; 13:2395-401.
19. Polson, Caten J, Yeaple R, Zander H. Histologic determination of probe tip penetration into gingival sulcus of human using an electrosonic pressure sensitive probe. J Clin peridontol. 1980;7:479-88.

20. Machtei E, Dunford R , Grossi S, Genco R. Cumulative nature of periodontal attachment loss. J Periodontal Res. 1994 ;29:361-64.

21. Silness J, Löe H: Periodontal disease in pregnancy. II. Correlation between. oral hygiene and periodontal condition. Acta Odontolgia Scandinavia 1964;22:121-35.

22. Loe H, Silness. The gingival index, and the retention index system. J periodontol.1967;38:610-16.

23. Paul S, Mark A, Gerald M. The treatment of intraboney defects with bone grafts. J Periodontol 2000, 2000;22:88-103.

24. Reynolds, M. A., Aichelmann-Reidy, M. E., \& BranchMays. Regeneration of periodontal tissue: bone replacement grafts. Dental Clinics.2010;54(1):55-71.

25. Ghanaati S, Barbeck M, Orth C, Willershausen I, Thimm $B$, Hoffmann $C$,et al. Influence of $\beta$-tricalcium phosphate granule size and morphology on tissue reaction in vivo. Acta biomaterialia.2010; 6(12): 4476-487.

26. Chatterjea, A. Pre-clinical validation of bone tissue engineering using mesenchymal stromal cells (Doctoral dissertation, Universiteit Twente)2012.

27. Pihlstrom BL, McHugh RB, Oliphant TH, Ortiz-Campos C. Comparison of surgical and nonsurgical treatment of periodontal disease. A review of current studies and additional results after 61/2 years. J Clin Periodontol 1983; 10:524-41.

28. Tonetti MS, Prato GP, Cortellini P . Factors affecting the healing response of intrabony defects following guided tissue regeneration and access flap surgery. J Clin Periodontol1996; 23:548-56.

29. Nowzari H, Matian F, Slots J . Periodontal pathogens on polytetrafluoroethylene membrane for guided tissue regeneration inhibit healing. J Clin Periodontol 1995;22:469-74.

30. D Trinath Kishore, Tushar Bandiwadekar, R Padma, Surangama Debunath, Profull., et al. Evaluation of Relative Efficacy of $\beta$-Tricalcium Phosphate with and without Type I Resorbable Collagen Membrane in Periodontal Infrabony Defects: A Clinical and Radiographic Study. J Contemporary Dent Practice, March-April 2013;14:193-201.

31. Stahl SS, Forum S. Histological evaluation of human intraosseous healing responses to the placement of tricalcium phosphate ceramic implants. Three to eight months. J Periodontol 1986;57:21. 
32. Baldock WT, Hutchens LH, Mcfalls WT, Simpson DM. Evaluation of tricalcium phosphate material in human periodontal osseous defects. J Periodontol 1985;56:1-7.

33. Snyder A, Levin M, Cutright D. Alloplastic implants of tricalcium phosphate ceramic in human periodontal osseous defects. J periodontol,1984; 55: 273-77
34. Krejic CB, Bissada NF, Farah C, Greenwell H. Clinical evaluation of porous and nonporous hydroxyapatite in the treatment of human intrabony defects. J Periodontol 1987;58:521-28.

35. Garrett S. Periodontal regeneration around natural teeth. Ann Periodontol 1996;1:621-66. 


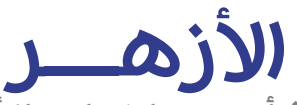 \\ مجلة أسيوط لطب الأسنان}

النشر الرسمي لكلية طب الأسنان

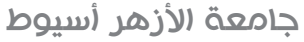

\title{
تأثير الفوسفات ثلاثثي الكالسيوم مع غشاء الكولاجين في الفي

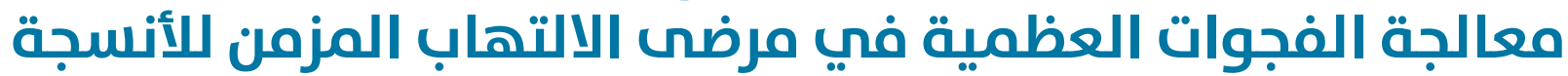 الحول سنية (دراسة اكلينيكية و بالتصوية فئير الشعاعي)
}

\author{
هانى كمال محمد * , خالد صديق ضيف الله حسن ،إبراهيم محمود موافى \\ 1. قسـم طب الفـم واهراض اللثـه والتشخيص والأشعـة, كليـة طب الاسـنان، (اسـيوط - بنين)، جـامعة الأزهر، هصر

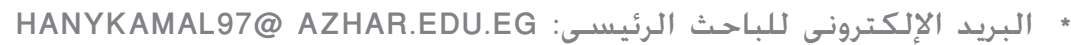

(لملخص :

الهدف: أجريت هذه الدراسـة لتقييهم البدائل العظمية من النوع ثلاثي فوسفات الكالسيوم مع غشاء الكولاجين في علاج الخلل العظمى حهول

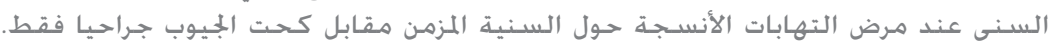

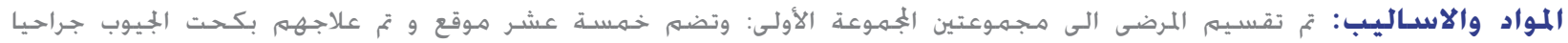

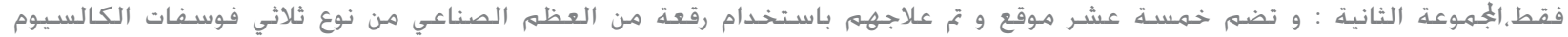

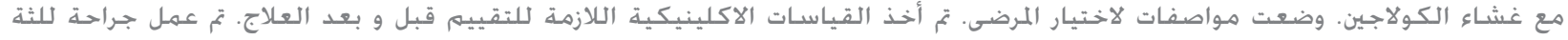

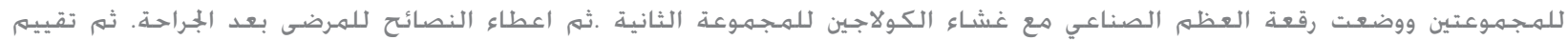

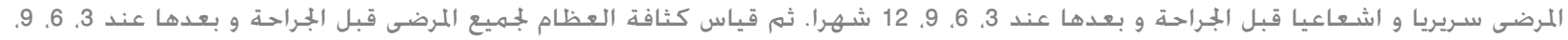

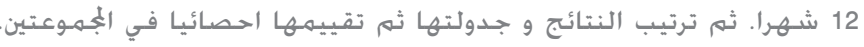

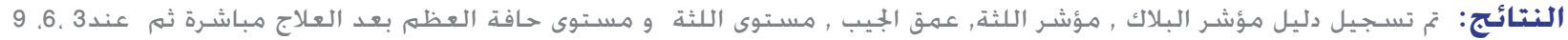

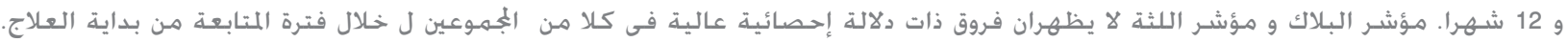

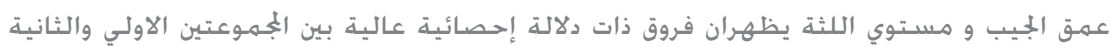

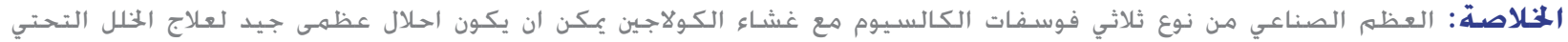
عظمى حول السنى ، كما انه أظهر نتائج ايجابية في أبحاث تأهيل الأنسجـة حول السـنية.

الكعلمات المفتاحية: البدائل العظمية من النوع ثلاثي فوسفات الكالسيوم ، غشاء الكولاجين ، جيوب سنيه، التهاب اربطه اللثة، قياس عمق الجيب اللثوي 